ROMAN MALARZ

Uniwersytet Pedagogiczny im. Komisji Edukacji Narodowej w Krakowie

\title{
Charakterystyka kandydatów na studia z turystyki i rekreacji na Uniwersytecie Pedagogicznym w Krakowie
}

\section{Studia na Uniwersytecie Pedagogicznym w Krakowie}

Uniwersytet Pedagogiczny w Krakowie powstał ponad 60 lat temu i jest najstarszą wyższą uczelnią w Polsce przygotowującą do zawodu nauczyciela. Należy równocześnie do największych uczelni publicznych Krakowa. Studiuje tu ponad 18 tys. studentów. Studia prowadzone są w systemie: studiów pierwszego stopnia (licencjackich, inżynierskich), studiów drugiego stopnia (magisterskich), studiów trzeciego stopnia (doktoranckich) oraz studiów podyplomowych (kwalifikacyjnych, doskonalących). W roku akademickim 2008/2009 na UP studiowało ponad 16 tys. studentów studiów stacjonarnych i niestacjonarnych pierwszego i drugiego stopnia, 2 tys. słuchaczy studiów podyplomowych oraz 220 studentów studiów doktoranckich. Kadra nauczycieli akademickich liczyła na początku 2009 roku ponad 800 osób. Kandydaci mieli do wyboru 23 kierunki studiów (Prestiż... 2009). Kilka kierunków pojawiło się po raz pierwszy w ofercie na rok 2009/2010.

\section{TURYSTYKA I REKREACJA - NOWY KIERUNEK STUDIÓW W InSTYTUCIE GEOGRAFII}

W roku 2009 na Wydziale Geograficzno-Biologicznym uruchomiono nowy kierunek studiów - turystykę i rekreację. Organizacyjnie funkcjonuje on w Instytucie Geografii. W lutym wspomnianego roku rozpoczęli studia w systemie niestacjonarnym studenci I roku studiów finansowanych z funduszy unijnych (60 osób). Choć są to studia niestacjonarne, są równocześnie niepłatne. Pierwszego października rozpoczęli zajęcia studenci turystyki i rekreacji studiów stacjonarnych (91 osób) i niestacjonarnych (159 osób). Analiza kandydatów na studia stanowi temat wielu opracowań. Wyniki kandydatów na egzaminach wstępnych na studia geograficzne na Uniwersytecie Jagiellońskim były tematem artykułów Z. Długosza (1977, 1987). Kandydatów na studia z turystyki i rekreacji na Uniwersytecie Łódzkim 
charakteryzowali autorzy z tamtejszego ośrodka (Jakóbczyk-Gryszkiewicz, Włodarczyk 1995, Jażdżewska, Wolaniuk 1996). Analizowano także powody wyboru kierunku studiów na Uniwersytecie Pedagogicznym przez młodzież wiejską (Malarz i in., w druku) i przyczyny niewielkiego udziału maturzystów ze wsi w staraniach o przyjęcie na studia wyższe (Szulc 2000).

Celem niniejszego opracowania jest charakterystyka kandydatów wybierających turystykę i rekreację. Znajomość tych zagadnień jest bardzo pomocna w organizowaniu akcji promujących studia na Uniwersytecie Pedagogicznym w Krakowie. Dotarcie do potencjalnych kandydatów z informacją o specyfice studiów stanowi zasadniczy cel działania Działu Promocji UP. Podobne działy funkcjonują także na innych uczelniach i pierwsza dekada XXI wieku dostarcza wielu ciekawych obserwacji na temat rywalizacji uczelni publicznych i prywatnych w docieraniu $\mathrm{z}$ ofertą studiów do potencjalnych kandydatów. Jest to problem nowy. Wiąże się on z szybkim wzrostem ilości uczelni prywatnych i nadchodzącym niżem demograficznym, w rezultacie którego maleje liczba maturzystów.

Turystykę i rekreację jako nowy kierunek studiów na Uniwersytecie Pedagogicznym otwarto w ramach poszerzania oferty studiów na Wydziale Geograficzno-Biologicznym. Ten kierunek działań okazał się trafny, gdyż na turystykę i rekreację zgłosiła się rekordowa liczba kandydatów. Na studia stacjonarne, gdzie planowano przyjąć 90 osób, zgłosiło się 1022 kandydatów. Był to w roku 2009 najbardziej oblegany kierunek studiów na UP w Krakowie. Komisja Rekrutacyjna przyjęła na pierwszy rok studiów na tym kierunku kandydatów, którzy osiągnęli ze świadectwa maturalnego średnią ponad 90\%. Do średniej liczono wszystkie zdawane przedmioty, preferując te, które kandydat zdawał w systemie rozszerzonym (mnożnik 1,5) oraz geografię (mnożnik 2 za system rozszerzony). Dużą popularnością cieszyły się także oba kierunki niestacjonarne. Na studia finansowane z funduszy unijnych kandydatów było ponad 400, a na studia niestacjonarne płatne ponad 160 . Łącznie na I rok turystyki i rekreacji przyjęto prawie 320 osób.

\section{TERYTORIALNE POCHODZENIE KANDYDATÓW}

Kandydaci na studia stacjonarne stanowili przytłaczającą większość (1022 osób) i na przykładzie tej zbiorowości zaprezentowano wybrane cechy tej grupy. Terytorialne pochodzenie kandydatów jest niezwykle ważną informacją dla działu promocji i jednoznacznie wskazuje, skąd należy także w przyszłości spodziewać się kandydatów. Na 1022 kandydatów aż $666(65,1 \%)$ pochodziło z województwa małopolskiego, w tym 301 z Krakowa. W dalszej kolejności sytuowały się województwa ościenne: podkarpackie - 117 kandydatów $(11,4 \%)$, śląskie - 103 osoby $(10,1 \%)$ i świętokrzyskie - 52 osoby $(5,0 \%)$. Łącznie z tych czterech województw pochodziło ponad $91 \%$ kandydatów. Z województw niegraniczących z Małopolską najwięcej kandydatów pochodziło z woj. lubelskiego - 31 osób (3,0\%). W mniejszych ilościach zgłaszali chęć studiowania turystyki i rekreacji kandydaci z innych województw. Z jednego tylko województwa - kujawsko-pomorskiego - nie było ani jednego kandydata (tab. 1). 
Tab. 1. Terytorialne pochodzenie kandydatów na studia stacjonarne z turystyki i rekreacji na Uniwersytecie Pedagogicznym w Krakowie w roku 2009

\begin{tabular}{|c|l|c|c|}
\hline Lp. & \multicolumn{1}{|c|}{ Województwo } & $\begin{array}{c}\text { Liczba } \\
\text { kandydatów }\end{array}$ & $\%$ \\
\hline 1 & małopolskie (bez Krakowa) & 365 & 35,7 \\
\hline & Kraków & 301 & 29,4 \\
\hline 2 & podkarpackie & 117 & 11,4 \\
\hline 3 & śląskie & 103 & 10,1 \\
\hline 4 & świętokrzyskie & 52 & 5,0 \\
\hline 5 & lubelskie & 31 & 3,0 \\
\hline 6 & fódzkie & 12 & 1,1 \\
\hline 7 & mazowieckie & 9 & 0,9 \\
\hline 8 & wielkopolskie & 2 & 0,4 \\
\hline 9 & dolnośląskie & 2 & 0,2 \\
\hline 10 & lubuskie & 2 & 0,2 \\
\hline 11 & pomorskie & 2 & 0,2 \\
\hline 12 & warmińsko-mazurskie & 2 & 0,2 \\
\hline 13 & zachodniopomorskie & 0,2 \\
\hline 14 & podlaskie & 2 & 0,2 \\
\hline 15 & opolskie & 2 & 0,1 \\
\hline 16 & kujawsko-pomorskie & 2 & \\
\hline
\end{tabular}

Źródło: Opracowanie własne na podstawie materiałów Komisji Rekrutacyjnej

\section{KANDYDACI ZE WSI I Z MIAST}

Województwa, z których pochodzi dominująca większość kandydatów, poza województwem śląskim, są województwami „wiejskimi” (Malarz i in., w druku). Oznacza to, że w województwach: małopolskim, podkarpackim, świętokrzyskim i lubelskim ludność wiejska dominuje nad ludnością miast. Ta struktura sprawia, że wśród kandydatów na studia udział młodzieży wiejskiej jest znacznie wyższy od średniej krajowej, która pod koniec XX wieku nawet na uczelniach rolniczych rzadko przekraczała 20\% (Szulc 2000). Tymczasem w roku 2009 na turystykę i rekreację na Uniwersytecie Pedagogicznym w Krakowie złożyło dokumenty 358 maturzystów ze wsi, co stanowiło 35\% ogółu kandydatów. Pozostałe $65 \%$ to kandydaci z miast, przy czym najwięcej z Krakowa. W tabeli 2 zaprezentowano liczebność i procentowy udział młodzieży wiejskiej i miejskiej, chcącej studiować omawiany kierunek. 
Tab. 2. Miejsce zamieszkania kandydatów na studia stacjonarne na kierunku turystyka i rekreacja w roku 2009

\begin{tabular}{|l|l|c|c|}
\hline Lp. & \multicolumn{1}{|c|}{ Miejsce zamieszkania } & $\begin{array}{c}\text { Liczba } \\
\text { kandydatów }\end{array}$ & $\%$ \\
\hline 1 & wieś & 358 & 35,0 \\
\hline 2 & miasto do 10 tys. mieszk. & 60 & 5,9 \\
\hline 3 & miasto od 10 do 50 tys. mieszk. & 172 & 16,8 \\
\hline 4 & miasto od 50 do 100 tys. mieszk. & 58 & 5,7 \\
\hline 5 & miasto od 100 do 500 tys. mieszk. & 72 & 7,0 \\
\hline 6 & miasto od 500 tys. do 1 mln mieszk. & 301 & 29,5 \\
\hline 7 & miasto powyżej 1 mln mieszk. & 1 & 0,01 \\
\hline
\end{tabular}

Źródło: Opracowanie własne na podstawie materiałów Komisji Rekrutacyjnej

Wśród kandydatów z dużych miast (powyżej 500 tys.) dominującą grupę stanowili kandydaci z Krakowa - prawie 30\% badanej zbiorowości. Tu także zaliczono jednego kandydata z Warszawy. Kandydaci z małych miasteczek (do 10 tys. mieszkańców) mieli niewielki, nie przekraczający 6\% udział. Dwie trzecie kandydatów to mieszkańcy wsi i Krakowa. Dominująca pozycja Krakowa jest widoczna także w zestawieniu z innymi miastami. Drugim miastem, z którego zgłosiło się najwięcej kandydatów, był Tarnów, skąd pochodziło 14 kandydatów (dla porównania Kraków - 301 kandydatów). Za Tarnowem plasują się: Nowy Sącz (13), Bielsko-Biała i Tarnobrzeg (12) oraz Rzeszów (10). Wśród miast, z których zgłosiło się więcej niż 5 kandydatów, odnotować należy tak odległe i słabo skomunikowane z Krakowem,

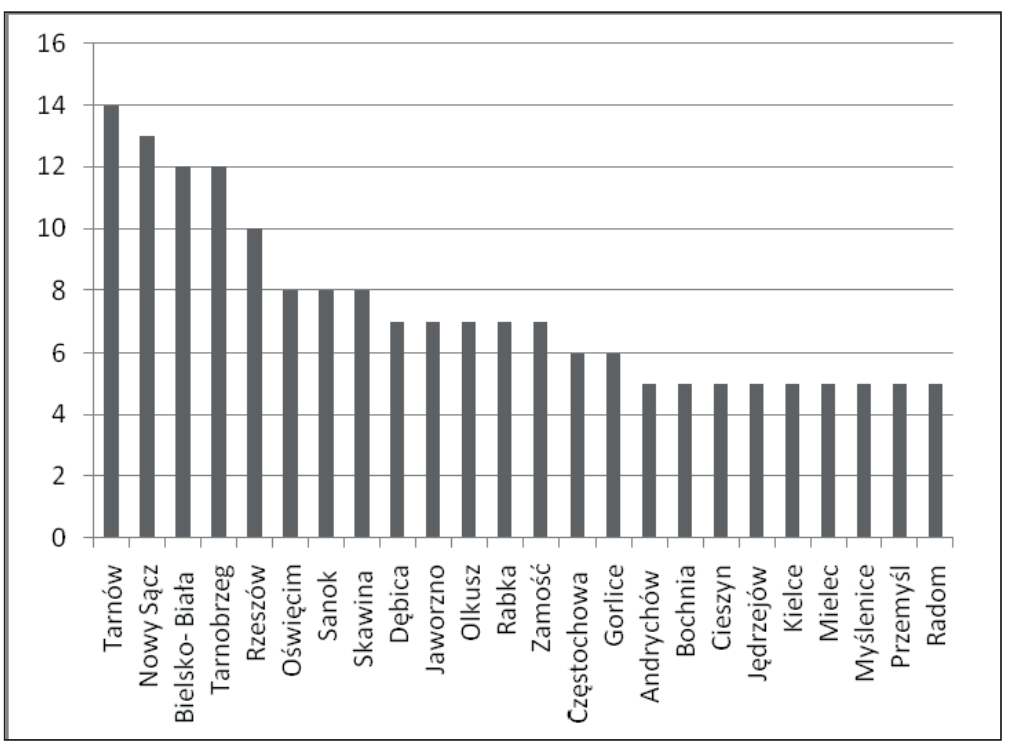

Ryc. 1. Miasta, z których pochodziło co najmniej 5 kandydatów na kierunek turystyka i rekreacja na UP w Krakowie w 2009 roku

Źródło: Opracowanie własne na podstawie materiałów Komisji Rekrutacyjnej 
jak: Sanok (8), Zamość (7) i Radom (5). Są jednak i takie miasta, z których chęć studiowania deklaruje niewielu kandydatów. W przypadku turystyki i rekreacji były to: Nowy Targ (1 kandydat) i Stalowa Wola (2 kandydatów).

\section{KOBIETY I MĘŻCZYŹNI}

Od czasów kiedy pierwsza studentka Nawojka musiała udawać mężczyznę, aby móc pobierać nauki w Akademii Krakowskiej, minęły wieki. Dziś płeć piękna dominuje na większości uczelni świeckich (wyjątkiem są uczelnie wojskowe). Także i wśród kandydatów na turystykę i rekreację dominacja kandydatek była wyraźna. W całej przebadanej zbiorowości stanowiły one 72,7\%. Największy udział kobiet odnotowano wśród kandydatów z województwa śląskiego $(81,7 \%)$. W dalszej kolejności wymienić należy województwa: małopolskie $(77,2 \%)$ i podkarpackie $(70,7 \%)$. Jedynie w wśród kandydatów z Krakowa (67,5\% kobiet) i województwa świętokrzyskiego $(65,4 \%$ kobiet) udział kobiet był niższy od średniej wyliczonej dla całej zbiorowości i nie przekraczał 70\%. Udział kobiet wśród przyjętych na studia wzrósł w stosunku do proporcji przedstawionych powyżej, a odnoszących się do kandydatów. Świadczy to o lepszych wynikach maturalnych kandydatek niż kandydatów.

\section{OSIĄGNIĘCIA KANDYDATÓW NA EGZAMINIE MATURALNYM}

W poprzednim rozdziale przedstawiono zasady punktacji świadectw maturalnych będących podstawą ubiegania się o przyjęcie na studia. Stosowane mnożniki (1,5 i 2) dla przedmiotów zdawanych w trybie rozszerzonym powodowały, że wielu kandydatów uzyskiwało za świadectwo maturalne średnią znacznie przekraczającą 100\%. Rekord należał do kandydatki z Węgierskiej Górki i wynosił 143,83\%. Na końcu rankingu znaleźli się kandydaci ze średnią poniżej 45\%. Takich kandydatów było 9, a najsłabszy z nich, krakowianin osiągną średnią 41,33\%. Te wartości wskazują jak wielkie było zróżnicowanie poziomu kandydatów. Wyliczona średnia dla całej zbiorowości wyniosła 76,0\%.

Pobieżna analiza danych zawartych w tab. 3 wskazuje na stosunkowo słabe wyniki maturalne kandydatów z Krakowa. Wyliczona średnia dla 301 kandydatów $(74,2 \%)$ jest niższa od średniej wyliczonej dla całej zbiorowości (76,0\%). Na tle maturzystów krakowskich bardzo dobrze prezentują się maturzyści z województw: śląskiego (85\%), mazowieckiego $(84,7 \%)$, małopolskiego $(78,2 \%)$ i podkarpackiego $(77,1 \%)$. Słabsi od kandydatów z Krakowa byli maturzyści z województw: świętokrzyskiego, lubelskiego i łódzkiego. Najgorsi kandydaci, jeśli chodzi o świadectwa maturalne, pochodzili z województwa wielkopolskiego $(54,7 \%)$. To zaskakujące stwierdzenie, gdyż opinie o kandydatach z tego województwa były dotąd pochlebne. Kolejnym zaskoczeniem jest wyższy poziom kandydatów ze wsi niż z miast. 
Tab. 3. Osiagnięcia kandydatów na turystykę i rekreację na UP w Krakowie (wyniki na świadectwach maturalnych) w podziale na województwa (pogrubioną czcionką zaznaczono wielkości powyżej średniej)

\begin{tabular}{|c|l|c|c|}
\hline Lp. & \multicolumn{1}{|c|}{ Województwo } & Liczba kandydatów & $\begin{array}{c}\text { Średnia ocen } \\
\text { na świadectwie (\%) }\end{array}$ \\
\hline 1 & zachodniopomorskie & 2 & $\mathbf{1 0 3 , 3}$ \\
\hline 2 & warmińsko-mazurskie & 2 & $\mathbf{9 2 , 6}$ \\
\hline 3 & śląskie & 12 & $\mathbf{8 5 , 0}$ \\
\hline 4 & mazowieckie & 9 & $\mathbf{8 4 , 7}$ \\
\hline 5 & lubuskie & 2 & $\mathbf{8 0 , 0}$ \\
\hline 6 & małopolskie (bez Krakowa) & 265 & $\mathbf{7 8 , 2}$ \\
\hline 7 & dolnośląskie & 117 & $\mathbf{7 7 , 7}$ \\
\hline 8 & podkarpackie & 1 & $\mathbf{7 7 , 1}$ \\
\hline 9 & opolskie & 301 & $\mathbf{7 7 , 1}$ \\
\hline 10 & Kraków & 52 & 74,2 \\
\hline 11 & świętokrzyskie & 12 & 74,0 \\
\hline 12 & lubelskie & 2 & 72,7 \\
\hline 13 & łódzkie & 2 & 64,5 \\
\hline 14 & pomorskie & 4 & 68,2 \\
\hline 15 & podlaskie & & 54,7 \\
\hline 16 & wielkopolskie & & \\
\hline
\end{tabular}

Źródło: Opracowanie własne na podstawie materiałów Komisji Rekrutacyjnej

\section{PRZYJĘCI NA STUDIA}

Na I rok studiów przyjęto w pierwszym etapie kandydatów, którzy uzyskali $100 \%$ i więcej. Takich osób było 92. Jednak spośród przyjętych zapisów na studia dokonało tylko 50 osób. Aż 42 bardzo dobrych kandydatów, w tym rekordzistka z Węgierskiej Górki $(143,83 \%)$, wybrało inną uczelnię, gdzie też znaleźli się na listach przyjętych. Przy kolejnej rekrutacji obniżono granicę do $90 \%$. W ostatecznym rozrachunku na I rok studiów stacjonarnych z turystyki i rekreacji przyjęto 106 osób. Wśród przyjętych $80 \%$ stanowiły kobiety. Przewaga kobiet odnotowana wśród kandydatów (72,7\%) po rekrutacji wzrosła prawie o 8\%. Zmieniły się także udziały młodzieży ze wsi i miast (ryc. 2). Wśród przyjętych wzrósł udział młodzieży ze wsi (wzrost o ponad $2 \%$ ), zmalał natomiast odsetek młodzieży krakowskiej (z 29,6\% do 27,6\%). Jeszcze większy spadek odnotowano wśród kandydatów reprezentujących miasta o liczbie mieszkańców od 10 tys. do 50 tys. (spadek o 3,5\%). Wśród maturzystów z miast dużych obserwuje się wzrost odsetka przyjętych w stosunku do procentowego udziału wśród kandydatów (ryc. 2). Oznacza to, że kandydaci ze wsi i dużych miast (od 50 tys. do 500 tys. mieszkańców) legitymowali się lepszymi wynikami na świadectwach maturalnych od swoich konkurentów z Krakowa i małych miast (do 50 tys. mieszkańców). 


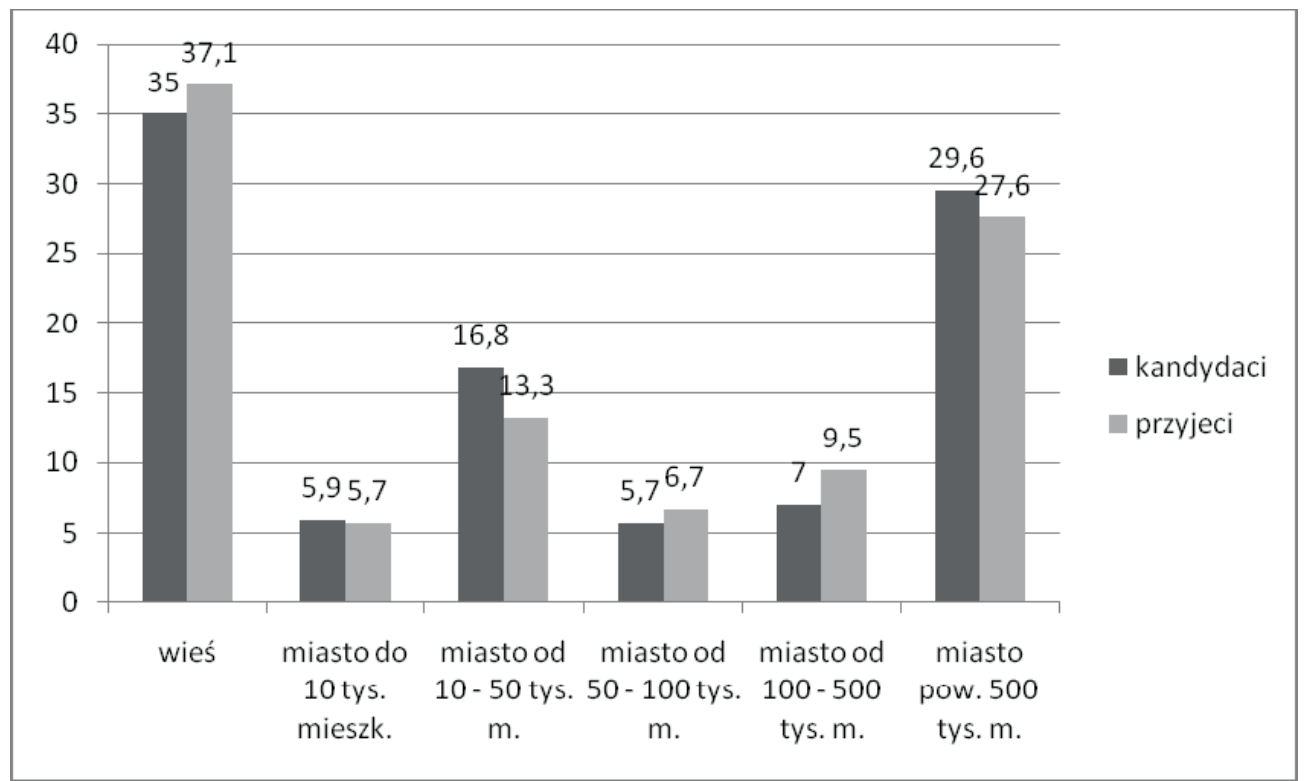

Ryc. 2. Odsetek kandydatów ze wsi i miast, przyjętych na studia z turystyki i rekreacji na UP w Krakowie w roku 2009

Źródło: Opracowanie własne na podstawie materiałów Komisji Rekrutacyjnej

\section{RODZINY KANDYDATÓW}

Wśród studentów I roku studiów stacjonarnych omawianego kierunku przeprowadzono badania ankietowe zmierzające do poznania środowiska, z którego wywodzą się studenci. Jedno z pytań dotyczyło rodziny studenta. Pytana osoba miała udzielić odpowiedzi, czy pochodzi z rodziny: pracowniczej, pracowniczo-rolniczej czy też rolniczej. Udzielone odpowiedzi wskazują na bardzo niski udział studentów z rodzin utrzymujących się z rolnictwa. Wśród studentów I roku jest ich raptem 5,2\%. To bardzo niewiele, zważywszy na to, że młodzież wiejska stanowi ponad 37\% badanej zbiorowości. Zdecydowanie dominuje młodzież $\mathrm{z}$ rodzin pracowniczych $(82,8 \%)$. Z rodzin mieszanych, pracowniczo-rolniczych pochodzi $12 \%$ studentów.

W ankiecie pytano także o wykształcenie rodziców. Matki legitymują się lepszym wykształceniem od ojców (ryc. 3). Zaprezentowany wykres dobrze ilustruje to zróżnicowanie. Podobne ankiety przeprowadzono także wśród studentów turystyki i rekreacji studiujących systemem niestacjonarnym. Nadając odpowiednią rangę dla odpowiedniego poziomu wykształcenia, uzyskano przeciętny wskaźnik, którego wielkość wahała się od 1 (wykształcenie podstawowe) do 6 (wykształcenie wyższe, magisterskie). Przeciętne wskaźniki wykształcenia rodziców studiów stacjonarnych, niestacjonarnych niepłatnych (finansowanych z funduszy unijnych) oraz niestacjonarnych płatnych zestawiono w tabeli 4. 


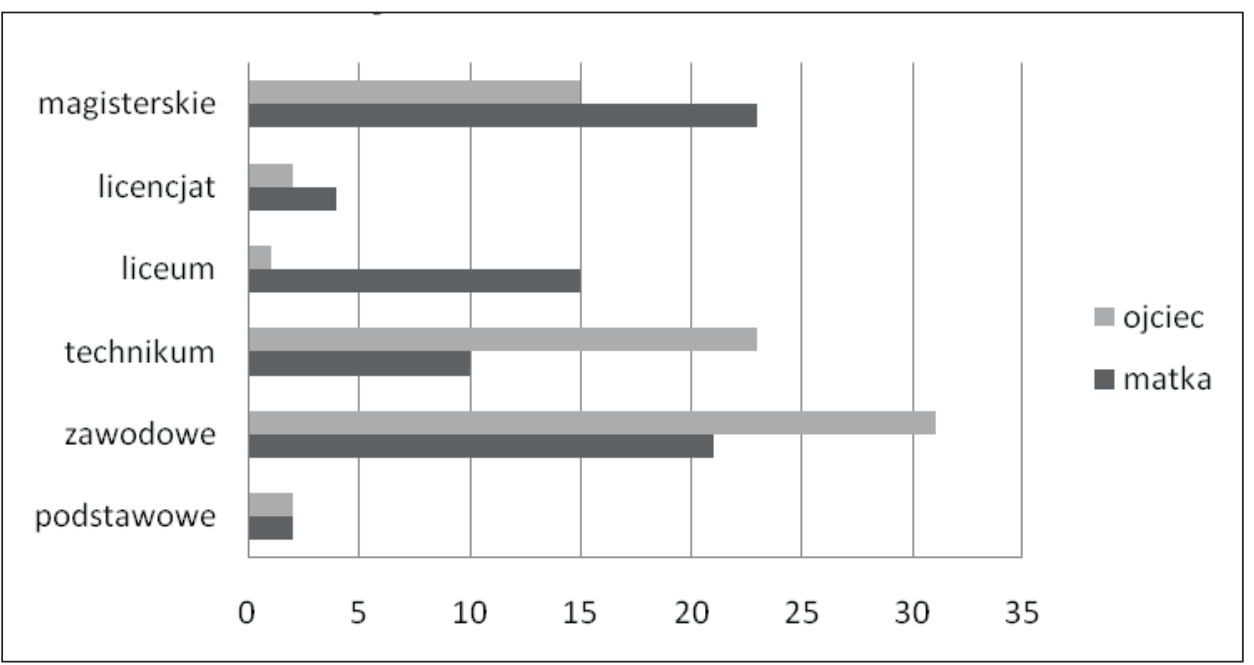

Ryc. 3. Wykształcenie rodziców studentów I roku studiów stacjonarnych z turystyki i rekreacji na UP w Krakowie w 2009 roku

Źródło: Opracowanie własne na podstawie badań ankietowych

Wnioski płynące z tabeli 4 są jednoznaczne. Dobrze wykształceni rodzice posyłają swe dzieci na studia niepłatne. Rodzice słabiej wykształceni, a więc prawdopodobnie ubożsi, posyłają swe dzieci na studia płatne. To jeden z problemów społecznych, z którym, jak na razie, nasz system szkolnictwa wyższego poradzić sobie nie może.

Tab. 4. Wskaźniki wykształcenia rodziców studentów turystyki i rekreacji w podziale na systemy studiów

\begin{tabular}{|l|c|c|}
\hline \multicolumn{1}{|c|}{ System studiowania } & Matka & Ojciec \\
\hline Studia stacjonarne & 3,8 & 3,1 \\
\hline Studia niestacjonarne, niepłatne (,unijne”) & 3,7 & 3,3 \\
\hline Studia niestacjonarne, płatne & 3,4 & 2,7 \\
\hline
\end{tabular}

Źródło: Opracowanie własne na podstawie badań ankietowych

\section{ZAKOŃCZENIE}

Niż demograficzny, w który Polska weszła w roku 1984, objawia się spadkiem urodzeń. W roku 2009, w którym rozpoczęto rekrutację na turystykę i rekreację na Uniwersytecie Pedagogicznym w Krakowie, podania składali maturzyści urodzeni w roku 1990 i 1991. W latach tych rodziło się w Polsce około 547 tys. dzieci. Przez następne kilkanaście lat odnotowywano systematyczny spadek urodzeń. Kryzysowy był rok 2004, kiedy to w Polsce 
odnotowano 351 tys. urodzeń (Szkolnictwo... 2009). Spadek urodzeń w ciagu kilkunastu lat o ponad 30\% musi mieć swoje konsekwencje w ilości kandydatów na studia. Prawdopodobnie w następnych latach nie uda się uzyskać takiego sukcesu rekrutacyjnego jaki wystąpił w roku 2009 , kiedy to na I rok studiów stacjonarnych zgłosiło się 1022 maturzystów. Stopniowo będzie ubywać kandydatów, a kryzysowym rokiem będzie 2022, kiedy to u bram uczelni pojawią się maturzyści urodzeni w roku 2004, w którym miało miejsce „dno” kryzysu demograficznego. $Z$ dużym zainteresowaniem należy śledzić przebieg rekrutacji w Instytucie Geografii w następnych latach.

\section{Literatura}

Długosz Z., 1987, Rekrutacja i wyniki egzaminów wstęnyych na kierunek geograficzny na Uniwersytecie Jagiellońskim w latach 1968-1985, Zeszyty Naukowe UJ, Prace Geograficzne, z. 70, s. 167-181

Długosz Z., 1977, Rekrutacja i wyniki egzaminów wstęnych na kierunek „, Geografia” Uniwersytetu Jagiellońskiego w niektórych aspektach społeczno-przestrzennych, Zeszyty Naukowe UJ, Prace Geograficzne, z. 44, s. 41-54

Jakóbczyk-Gryszkiewicz J., Włodarczyk B., 1995, Charakterystyka kandydatów na studia z geografii turyzmu i hotelarstwa na Uniwersytecie Łódzkim w roku akademickim 1994/95, Turyzm, t. 5, z. 1 , s. $84-88$

Jażdżewska I., Wolaniuk A., 1996, Charakterystyka kandydatów na specjalność geografia turyzmu i hotelarstwa Uniwersytetu Lódzkiego w roku 1995, Turyzm, t. 6, z. 2, s. 121-126

Malarz R., Rettinger R., Warcholik W., (w druku), Preferencje młodzieży wiejskiej w wyborze kierunku studiów (na przykładzie Uniwersytetu Pedagogicznego w Krakowie), Wydawnictwo WSEiP, Kielce

Prestiż, profesjonalizm, nowoczesność, 2009, folder reklamowy Uniwersytetu Pedagogicznego w Krakowie, Kraków, s. 28

Szkolnictwo wyższe w Krakowie - perspektywy rozwoju w kontekście zmian demograficznych. Prognoza na lata 2009-2014, 2009, praca zbiorowa pod red. K. Jakóbika, Urząd Statystyczny w Krakowie, Kraków

Szulc T., 2000, Wyjść z wiejskiego kręgu niemocy, Głos Uczelni, nr 84, Wydawnictwo Uniwersytetu Przyrodniczego we Wrocławiu, Wrocław, s. 16-24

\section{Characteristics of Tourism and Recreation Studies Candidates at the Pedagogical University of Cracow}

In year 2009, Institute of Geography of the Pedagogical University of Cracow created a new course of study, i.e. Tourism and Recreation. A record breaking number of 1022 prospective students applied for enrolment for the first year of study. A great majority of candidates came from the Małopolskie voivodship and the city of Cracow (the total of $65.1 \%$ ). A significant number of applicants came also from the neighbouring provinces, i.e. Podkarpackie (11.4\%), Śląskie (10.1\%) and Świętokrzyskie $(5.0 \%)$. Over $35 \%$ of candidates came from rural areas, which constitutes a fairly high percentage value on the national scale, due to the fact that the Małopolskie, Podkarpackie, and Świętokrzyskie voivodships constitute territorial units where rural residents are outnumbered by rural population. Admission was based on applicants' results obtained in the secondary-school-leaving exam. The recruitment committee calculated the average of grades obtained from all exams, applying 1.5 conversion factor to advance level exams, and 1.5 and 2 conversion factor to the basic and advanced level exam in geography, respectively. Consequently, the highest-scoring applicants exceeded the value of $100 \%$. The highest 
score was achieved by a candidate from Wegierska Górka (143.83\%). The applicant with the lowest score came from Cracow (41.33\%). The average grade obtained from the secondary-school leaving exam for all applicants equalled $76 \%$. The majority of candidates were women $(72.7 \%)$, who also "improved" their results and constituted $80 \%$ of students admitted to the first year of study.

Prof. UP dr hab. Roman Malarz

Uniwersytet Pedagogiczny w Krakowie

Instytut Geografii

Zakład Turystyki i Badań Regionalnych

e-mail: rmalarz@up.krakow.pl 